\title{
Stay with Me: Factors Influencing Teacher's Retention in Private Elementary Schools
}

\author{
Jasmin M. Sumipo, PhD \\ Principal, \\ Mater Dei College High School Department, \\ Tubigon, Bohol, Philippines
}

\begin{abstract}
This research study sought to find out the factors which influence teachers' decision to stay among the selected private elementary schools in Tubigon, Bohol. A researcher made questionnaire based on Fredrick Herzberg's Motivation- Hygiene Theory supplemented with informal interviews were used to gather the perceptions of the research participants. This quantitative-qualitative study used purposive sampling to determine the eighteen teacher participants from the three private elementary schools. Using a weighted mean formula to interpret the data, findings revealed that motivational factors on the job are strong influencing factors responsible for teachers' retention. Despite the low salary they received, the participants chose to stay because they felt satisfied in other areas. Truly, intrinsic motivational factors are stronger forces that instill teachers' loyalty to the school. This is in congruence with Herzberg Theory which states that the higher the motivational factors, the greater the percentage of worker's retention.
\end{abstract}

Keywords: hygiene, motivation, private school, retention factors, teachers

The retention of teachers in private schools has been a continuing concern for teachers and school administrators in recent years. The Philippines is also among the countries that is experiencing a constant turnover of its teachers especially at the basic education level. Significant numbers of teachers leave the teaching force each year. The issue of teacher retention becomes even more critical when added to the condition of teacher shortages (Martson, 2014).

Teacher retention is critical to school success for several reasons. One is financial. Recruiting, hiring, orienting and providing initial professional development can be financially burdensome, specially to small schools. Moreover, unlike other professions, teaching positions cannot simply go unfilled. Yet another compelling reason on the importance of retaining teachers is that inexperienced teachers do not have the same impact on student learning as their more experienced coworkers. Additionally, research shows again and again that teachers are the single most important factor in student achievement.

Goodlad in Martson (2014) said that the ability to develop successful schools is directly related to the ability to attract and retain quality teachers." Dela Cruz (2016) concurred to this when she said that the effectiveness of education depends on retaining teachers. To clarify, retention refers to the decision of a teacher to stay in the school despite the end of the term of contract as influenced by the motivation factors defined by Herzberg in his Motivation Theory. According to Herzberg' Two Factor Theory, hygiene factors are those factors which when adequate/reasonable in a job, pacify the employees and do not make them dissatisfied. These include school administration and policy, pay and benefits, job security, interpersonal 
relations, work conditions, and work assignment. On the other hand, motivation factors are psychological needs that were perceived as an additional benefit. These include recognition, sense of achievement, growth and promotional opportunities, responsibility and meaningfulness of the work.

Maslow's hierarchy of needs and motivation theories may help to address employee retention. Maslow proposed that motivation is the result of a person's attempt at fulfilling five basic needs: physiological, safety, social, esteem and self-actualization. Therefore, it is essential school administrators to understand the psychological processes involved in motivation so that they can effectively direct teachers towards institutional goals.

\section{METHODOLOGY}

In consideration of ethical standards, permission of the three school heads was asked before the conduct of the study. The descriptive research aimed to determine the reasons that contribute to teachers' retention in three private elementary schools. The data were primarily gathered through a researcher- made survey questionnaire, and supplemented through informal interviews. Participants' profile such as years of service in teaching and educational qualifications were sought as they were deemed vital information in the study. Participants were then made to select among the five options in a Likert scale describing their attitudes in each indicator. To interpret the results, percentage and weighted mean were used. The resulting weighted mean utilized the following intervals for interpretation: $5.00-4.21$ Critically Important, 4.20 - 3.41 Very Important, 3.40- 2.61 Fairly Important, 2.60-1.81 Slightly Important, and 1.0-1.81 Unimportant.

\section{RESULTS AND DISCUSSION}

Number of years in teaching is an important profile in the study. As indicated in the table, ten or fifty- five percentage of the respondents have served the school between six to eight years. Considering that the term of contract for probationary teachers is just two to three years, remaining in a same school for more than five years is such an achievement.

Table 1: Years of Service in Teaching

\begin{tabular}{ccc}
\hline Years of Service & Frequency & Percentage (\%) \\
\hline 3-5 years & 3 & 16.66 \\
6-8 years & 10 & 55.55 \\
9-11 years & 4 & 22.22 \\
12 years and above & 1 & 5.55 \\
\hline
\end{tabular}

Cabigas (2019) mentioned that based on the 2018 Philippine Statistics Authority (PSA) report, the country faced a net loss of 132 teachers every year which meant that more individuals left the profession as compared to the ones entering it. Thus, retaining teachers in school after the end of their contract calls for a celebration on the part of school administrators.

Table 2: Participants' Educational Qualifications

\begin{tabular}{ccc}
\hline Highest Educational Degree & Frequency & Percentage (\%) \\
\hline Earned Masters' Units & 12 & 66.66 \\
Masters' Degree Holder & 4 & 22.22 \\
Earned Doctoral Units & 2 & 11.11
\end{tabular}


One of the strongest motivating factors in the workplace is opportunity provided for advancement. In the case of teachers, proceeding to higher educational degrees is a must if one wants to step up in rank and be promoted to a higher position. Within their years of stay in the private schools, it is notable that a large number of teachers, that is 66.66 percent, has earned masters' units. Clearly, administrators have encouraged their teachers to enroll in further studies. Taking graduate degree programs provide teachers with theorical and practical insights, and teacher's knowledge of education theory creates positive impact when applied into practice. Additionally, it is worthy to note that growth and promotional opportunities are among the motivation factors which influence teacher's retention at schools.

Based on Herzberg, motivational factors are inherent to work and yields positive satisfaction. These internal factors respond to the psychological needs of teachers and motivate the employees for a superior performance. Hygiene factors, on the other hand, are external factors which are need to meet the physiological needs of teachers. Though these do not lead to longterm positive satisfaction, hygiene factors must be met to keep employees from being dissatisfied.

Table 3: Factors that Contribute to Teachers' Retention

\begin{tabular}{|c|c|c|}
\hline Indicators & Weighted Mean & Interpretation \\
\hline 1. Compensation & 2.82 & Fairly Important \\
\hline 2. Fringe benefits (healthcare, free tuition, retirement) & 3.00 & Fairly Important \\
\hline 3. Professional advancement and growth & 4.15 & Very Important \\
\hline 4. Relationship with employers & 3. 44 & Very Important \\
\hline 5. Relationship with colleagues & 3.72 & Very Important \\
\hline 6. Relationship with parents and guardians & 3. 41 & Very Important \\
\hline 7. Relationship with students & 3.55 & Very Important \\
\hline 8. Company policies & 2.23 & Slightly Important \\
\hline 9. Love of teaching & 4. 35 & Critically Important \\
\hline 10. Sense of Responsibility to Do the Job & 4.29 & Critically Important \\
\hline 11. Security and tenure & 2.95 & Fairly Important \\
\hline 12. Recognition and Awards & 4. 10 & Very Important \\
\hline 13. Sense of Fulfillment over Students' Success & 4.22 & Critically Important \\
\hline 14. Workplace facilities & 2. 92 & Fairly Important \\
\hline
\end{tabular}

Analysis on data of table 3 revealed that teacher participants rated love of teaching, sense of responsibility to do the job, and sense of fulfillment over students' success as critically important. Teachers should be given a sense of responsibility if they are to feel a sense of ownership and self-satisfaction on their job. In addition, many teachers find personal fulfillment in knowing that they have been part of their students' development and guiding their students to discover their own paths. Teachers who teach subject they are passionate about have the opportunity to talk about their passion and even to share this passion with their students. The current research relates to the findings of Liu et al. (2000) as cited by Locklear (2010) on the major reasons for choosing a teaching career as the value of meaningful work, love of working with children, and the enjoyment of pedagogy within their specific subject matter.

Professional advancement and growth as well as recognition and awards were rated as very important by the teacher participants. Through continuing education, teachers do not only advanced professionally but also constantly improve their skills to become more proficient at their jobs. A positive correlation between professional advancement and job satisfaction has been established by many researches. Professional advancement and growth also known as 
promotion opportunities is an important aspect of a worker's career and life. It can have a significant impact on other job characteristics such as responsibilities (Mustapha, $\mathrm{N}$ and Zakaira, CZ 2013). Akin to professional advancement is recognizing and awarding teachers who have performed well. Employee recognition is the act of acknowledging and appreciating an employee's work. The main goal of employee recognition is to let employees know that the effort they put in their job and the work results they achieved are valued and appreciated. It is well to remember that reward and recognition have great impact on motivation of the employees (Danish, R.Q. \& Ali, U. 2010).

In order to feel successful, teachers need support from their colleagues, and administrators within their work environment (Johnson, 2006). This current research showed that indeed relationships with colleagues, students, employers, and parents and guardians were all rated as very important. Teachers spend most of their time with their co-teacher and their students. Hence, it is not surprising that a good relationship with them is deemed important. Positive interpersonal relationships in their school are very important as they offer affiliation and support ((Rhodes et al., 2004). Moreover, relation with employers is important since the employee and employer relationship is an intrinsic element to an institution's success and growth (Craig, 2017). Success or failure of employee's perception of human resource practices depends on the relationship between organization and employees (Kuvaas, 2008),Additionally, another influential stakeholder of education is the parents and guardians. Positive parentteacher relationships are crucial to the success of individual learners and can boost the morale of teacher.

Security and tenure, workplace facilities and compensation were rated as fairly important by the research participants. Security and tenure is the right of an office-holder against unlawful dismissal from work. In the study of Cohen (2010), he found out that while the relation between organization commitment and tenure was strongest for the oldest tenure subgroup, this is not true for the youngest subgroup. Consequently, since majority of the participants can be considered relatively new to the workplace, they did not consider security and tenure of utmost importance. Similarly, though workplace facilities increase productivity, to most participants, workplace environment, in terms of relationship, is more important.

Compensation and fringe benefits were both considered as fairly important by the participants. Although many organizations focus on monetary aspect as one of the strongest drives affecting teachers' retention., ironically, the current research concurs with past researches which have indicated that the decision to remain in the work place is due to combination of several factors. Liu \& Meyer (2005) as cited by Kersaint (2007) found out that teachers are less likely to resign because of salary when other working conditions are satisfactory. Because of this, it may be more important to focus attention on providing teachers needed administrative support rather than focus solely on increasing teacher compensation.

On the bottom of the list is company policies. Considering that majority of the teacher participants are new to the workplace, they do not have much point of comparison in terms of the policies enforced by different institutions. Also to be taken into account is the fact that the locale of the study are Catholic schools whose vision, mission, and goals are coherent with Christian principles and yielding to humanitarian considerations.

\section{CONCLUSION}

Retention of seasoned teachers equates to the delivery of quality education. Higher rates of retention instill confidence among educational stakeholders, primarily the learners, but additionally, the parents, guardians, and significant others. 
The findings of this study suggest that motivational factors, specifically those related to the job itself including the love of teaching and feeling a sense of fulfilment, are the strongest influences of teachers' decision to stay in the private schools. Although these are psychological factors and are intrinsic in nature, a supportive environment in terms positive relationship with co-workers, administrators, parents, and students will certainly encourage teachers to remain in the work place. Private schools may not be able to compete with public schools in terms of compensation and fringe benefits, but provided that other factors are satisfactorily met, teachers will relegate these factors at the bottom in favor of more noble reasons. Teachers may not always seek greener pastures, but they will always choose a workplace that nurtures.

\section{References}

Martson, T. Factors that contribute to teacher retention in high-poverty middle schools (2014). Electronic Theses and Dissertations Paper 2374. (Online) Retrieved (December 5, 2019) from http://dc.edu/etd/2374.

Dela Cruz, R.A. (2016). Attrition of Private and Public School Teachers: A Comparative Analysis. Advances in Social Research, 2(1), 29-32.

Cabigas, VL (2019) Who Let the Teachers Out? Exploring the Main Factors which Contribute to Teacher Attrition in Philippine Schools. (Online) Retrieved (February 14, 2020) from https://www.academia.edu.

Locklear, T (2010) Factors contributing to Teacher Retention in Georgia (retrieved January 20, 2020) from cumen.lib.ua.edu/content/u0015/0000001/0000298/u0015_0000001_0000298.pdf.

Mustapha, N and Zakaira, CZ. (2013) The Effect of Promotion Opportunity in Influencing Job Satisfaction among Academics in Higher Public Institutions International Journal of Academic Research in Business and Social Sciences March 2013, Vol. 3, No. 3 (20-26).

Danish, R.Q. \& Ali, U. (2010). Impact of Reward and Recognition on Job Satisfaction and Motivation: An Empirical Study from Pakistan. International Journal of Business and Management. 5. 10.5539/ijbm.v5n2p159.

Johnson, S. M., \& Birkeland, S. E. (2003). Pursuing a "sense of success": New teachers explain their career decisions. American Educational Research Journal, 40(3), 581-617.

Craig, W. (2017) Why a Strong Employee/Employer Relationship Is Important www.forbes.com/sites/williamcraig/2017/09/20/why-a-strong-employeeemployer-relationship-isimportant/\#5ea112d764d9.

Rhodes, C., Nevill, A. M., Allan, J. (2004). Valuing and supporting teachers: A survey of teacher satisfaction, dissatisfaction, morale and retention with an English Local Education Authority. Research in Education, 71, 67-80.

Kuvaas, B. (2008). An exploration of how the employee-organization relationship affects the linkage between perception of developmental human resource practices and employee outcomes. Journal of Management Studies, 45(1), 1-25.

Cohen, A. (2010) Age and Tenure in Relation to Organizational Commitment: A Meta-Analysis Journal Basic and Applied Social Psychology Volume 14, 1993 - Issue 2.

Kersaint, J, Lewis, J, Potter, R and Meisles, G. (2007) Why teachers leave: Factors that influence retention and resignation ( Teaching and Teacher Education 23 (775-794). 